\title{
Construction and Practice of the New Business Specialty Talent Cultivation Mode
}

\author{
Xiaokong Xiao \\ Department of Business Administration, Chongqing Education College \\ Chongqing 400067, China \\ Tel: 86-23-6265-8034Ｅ-mail: cqjyxxk@163.com
}

\begin{abstract}
The vocational education of business should actively adapt the demands of the domestic and foreign business development to cultivate high-quality applicable talents with international knowledge. The traditional business specialty teaching and the talent cultivation mode have not followed the domestic and foreign market demands, and are difficult to fulfill the requirements of multiple business posts in domestic and foreign enterprises, and the only way is to reform. In this article, the target of "three innovations and one construction" about the higher vocational business specialty teaching reform and the talent cultivation mode are proposed, i.e. actualizing the professional teaching innovation of "skills + arts", the teacher construction innovation of "double teachers + famous teachers" and the fortune ability innovation of "employment + self-employment", and aiming at these targets, deepening the cognition and practice of the reform, exploring and constructing the higher vocational Business Specialty Talent Cultivation system with demonstrative effect, strong pertinence and implementation feature, and realizing the objective to strengthen the professional education and serve for the economic and social developments.
\end{abstract}

Keywords: Business talent, Cultivation mode, Construction, Practice

\section{Analysis of the actuality of the demand of business specialty talents and the problems existing in professional teaching}

As the national strategic target of building a well-off society in an all-round way and constructing the harmonious society was established, the development tendency which drive the new industrialization and the agricultural industrialization by the informationization under the whole planning of the scientific development view is more and more obvious, and the development speed of cities and villages is quicker and quicker, and the enterprise management is more and more active, and various business activities are more and more frequent. In addition, after China entered into WTO, the domestic and foreign market competition is more and more drastic, and the business management and service is more urgent and important, and the demand of the professional talents who can manage and serve for the business activities increases obviously, and the requirement of talent quality quickly increases, and at present, the demands of the business specialty talents have exceeded the supplies.

The problems existing in the teaching of the higher vocational business specialty are obvious at present. Because the business specialty is a relatively mature specialty, and the cultivation of the business specialty talents in Chongqing Education College still follows the traditional mode, and some practice parts are limited by the subjective conditions, so the graduates of the business specialty generally have narrow specialty views, low quality, weak actual working capability, deficient innovation ability and bad strategies and arts processing domestic and foreign business competitions, which reflect that the cultivation system of the business specialty in the Chongqing Education College still has serious deficiencies such as blurry cultivation target, unreasonable course system design, old teaching contents, single teaching method and lagged education ideas.

To meet the higher vocational education with the international requirements and drive the teaching reform and development of the business specialty in the Chongqing Education College, the talent cultivation system especially the teaching system reform should be further deepened, the talent cultivation mode should be rebuilt, the cultivation target should be reoriented, the structure, system and contents of the specialty course should be updated and integrated, the teaching plan should be optimized, the teaching method should be improved, the teaching idea should be actively transformed, and the vocational education theoretical level, the schooling level and the talent cultivation quality of the business specialty should be further enhanced.

\section{The business talent cultivation mode must be reconstructed and the specialty teaching must be reformed}

To quicken the talent cultivation of the business specialty, the opportunities and challenges coexist and the way consists in the reform. 


\subsection{Targets of the reform}

The reform of the business specialty should cooperate with the teaching reforms of other relative specialties, depend on the background knowledge and skills needed in other specialties such as food business, drag business, auto business, tourism business, electric business, international logistics, marketplace management and business negotiation, strengthen the cultivation of the application ability, enhance students' employment strengths, and realize the "three innovations and one construction", i.e. the professional teaching innovation of "skills + arts", the teacher construction innovation of "double teachers + famous teachers" and the fortune ability innovation of "employment + self-employment". By the reform, the higher vocational business specialty talent cultivation system with demonstrative effect, strong pertinence and implementation feature can be explored and constructed, and the brand specialty of the higher vocational business can be formed.

\subsection{Ideas of the reform}

Surrounding the domestic and international business markets, the college should widely and deeply survey the demands of the business management talents and the service post (group) talents, investigate the basic responsibilities of various business posts (groups) clearly, confirm the knowledge, abilities and comprehensive qualities that students should grasp, establish the teaching plans according the cultivation targets of the specialty and the domestic and foreign enterprise business demands, organize and implement the teaching reform strategies full of pertinences, and realize the teaching reform targets of "three innovations and one construction".

Therefore, the talent cultivation targets of the business specialty are to cultivate the high-quality and applicable talents who completely develop from morality, intelligence, gym and arts, have wide international view, sensitive vocational consciousness, good vocational morality, comprehensive quality, good specialty knowledge and obvious strong suits, adapt relative business posts (group) in various enterprises, know how to manage, survey, plan, operation and serve.

The quality of the cultivation targets include following connotations.

(1) The connotation of knowledge structure. The students should know the basic principle of Marxism and the basic theory of the socialism market economy, possess socialism morality and legal concepts, grasp the relative knowledge about the market investigation and prediction, the business negotiation, the business plan, the business development, operation and service, be familiar with the general application knowledge of the computer, and the knowledge to develop the business operation by the internet and other modern communication and E-business measures, and basically grasp one foreign language to fulfill the requirements of the relative works about the business specialty.

(2) The connotation of capability structure. The students should possess the strong business plan capability, the business negotiation capability and the business risk solution and emergency capability, the good capability to implement business prediction and analysis, product distribution and business service and develop the business market, the capacity to develop the business by the computer and implement business management and service by other measures, the good capability of public expression, self-learning and information acquisition and processing, and the standard public relation manners and strong public relation capability.

(3) The connotation of quality structure. The students should possess good ideological standards, vocational morality and psychological quality, strong team spirit, excellent humanistic quality, good tradition and work style of plain living and hard struggle to ensure students can not only deal with the public relationships, but avoid losing the competitive consciousness.

(4) The connotation of graduate characteristic. The students should possess further international view, sensitive business consciousness, strong domestic and international business management and service ability and the ability to develop the domestic and foreign markets and effectively implement the business affairs; possess the applied abilities about the foreign language, computer and internet adapting with the professional works. Except for acquiring the parchment of the specialty, they should acquire above one middle-class vocational qualification certificates such as the national "Business Strategist", "Marketing Teacher", "Public Relations Officer", "Human Resource Specialist", "SEC", "Logistics Manager" and "Customs Specialists", and the second-class certificate of the mandarin, the national first-class certificate of computer, and the grading certificate of English.

\section{Basic measures of the construction and practice}

\subsection{Forming the talent cultivation characters of "one, two, three, four"}

"One" main line means to build the business plan, business management and business service ability as the main line. "Two" integrations mean the integrations of the basic quality of specialty and the specialty skills and strong suits. The basic quality of specialty is the important support of graduates' basic quality and specialty ability, and the specialty skills and strong suits are the key to strengthen graduates' employment strengths. "Three" equal attentions mean to pay equal attention to the theory and practice, pay equal attention to knowledge learning and ability cultivation, and pay equal attention to school cultivation and enterprise experience. "Four" requirements include the teacher quality 
requirement of "double teachers", the teaching management requirement combining the academic year system and the credit hour system, the exam requirement to give priority to practice skills and combine with various exam measures, and the requirement possessing the diploma certificate the vocational qualification certificate at the same time.

\subsection{Constructing the cultivation courses of "three modules"}

The college should rebuild the course system and structure, and update the teaching contents, and integrate the cultivation courses to be three modules including "basic knowledge and capability, specialty knowledge and skills, vocational development direction". By the developments of the courses in various aspects, the college can realize the integration of the vocational basic knowledge, vocational quality, vocational post ability and specialty strong suits for business talents, improve the enhancement of talents' comprehensive quality and the formation of the practice and innovation capability to ensure the organic uniform of talents' morality, knowledge, ability and comprehensive quality, and make them possess the necessary capabilities adapting various business posts (group), and the self-development capability.

The module of the basic knowledge and capability includes the courses such as basic foreign language, basic knowledge and application of computer, basic knowledge and application of internet, economy and law bases, management principle, application writing and public relation manners. The module of the specialty knowledge and capability includes the cultivation contents such as business investigation and prediction, business plan, business negotiation, business broker and agent, business SEC affairs, trade and logistics, auto business and electric business. The module of the vocational development direction includes the courses such as the post knowledge and skills in business English, business management, international trading, financial affairs and finance taxation, VF database application, and auto driving. At the same time, many courses in other specialties are provided to be selected by students according to their interests and favors in order to cultivate and develop graduates' individuality of business management and the strong suits of business service.

\subsection{Constructing the cooperation system of "production, learning and researching"}

The college should actually ensure the cooperation of "production, learning and researching" to form the uniform system in the schooling target, acting rule, time and space guarantee, responsibility sharing and benefit distribution, and live up to reasonable planning, standard running, effective implementation and powerful guarantee.

First, the college should establish the "production, learning and researching" cooperation committee with multiple enterprises, and the teaching instruction committee of the business specialty to comprehensively instruct the practice of the talent cultivation reform in the specialty. Two committees should periodically implement the special discussion and market investigation analysis, draw on advices of the employers, timely find out the new changes about the demands of the business talents, and amend the cultivation plan and contents.

Second, the college should associate with enterprises to cultivate talents and reduce or eliminate graduates' employment adaptation period. The exercitation and practical training of the specialty and the business project design should closely combine with various business flows to strengthen the mutual understanding of enterprise and graduates, reduce the blindness of occupation selection and talent selection, and reduce the employment adaptation period, and try to realize the "seamless connection" of graduates and posts in the enterprise. The college should advocate and encourage graduates to choose their occupations according to their own interests, strong suits and concrete property of the business posts (group), combine with self-employment, and develop and utilize effective employment resources. The college should develop the cooperation with enterprises, enhance teachers and students' capabilities of business management, service and R\&D, accelerate the transformation of the scientific and research results, and make enterprises more possess competitive strengths in business development, business service and business management.

\subsection{Constructing the course system and teaching contents adapting the professional cultivation targets}

The college should implement the principle that the theoretical knowledge "must be used enough" and "is oriented by the application capability". By the interview, discussion and argumentation with experts surrounding enterprise business development and management, the college should further confirm the cultivation target of the specialty, and the responsibilities of the business posts (group), emphasize the application attention of the theoretical teaching, pay equal attention to the application of the theoretical knowledge and practical ability, and strengthen the pertinence and practicability.

\subsection{Strengthening the reforms of the course system and the teaching contents}

The college should try to overcome the method constructing the teaching contents and course system by the traditional theoretical teaching, change the orientation taking the social demand and post responsibility as the center, and confirm the specialty cultivation target and the talent cultivation specification. Except for the public courses regulated by the nation, the course setting should give priority to necessary knowledge and skill courses about graduates' knowledge, ability and quality, and assist with courses of general knowledge and quality development which can help to form 
comprehensive quality, and try to break the limitations among subjects, strengthen the integration of course contents, simplify old knowledge contents, increase the content of modern technical knowledge, and embody the advance of the course content. The courses should accord with the target of the talent cultivation. Teachers should take the application as the intention when organizing teaching content, take the application ability cultivation as the start and end, and confirm the teaching content according to the demands of the ability cultivation.

(1) Perform the course selection system and encourage students to choose their courses. The college should fully respect students' independence of learning and cultivate students' independent personality and development potential; strengthen the practice teaching adapting the target of the specialty cultivation; not only pay attention to the organic association of the specialty practice training and the theoretical teaching, but avoid the over-adherence of the practice training to the theoretical teaching and make the practice teaching to possess relative independence; try to construct the practice teaching integrating "course practical training, (enterprise) market exercitation, graduate design, skill training, and vocational qualification exam", in which the proportion of the practice courses should occupy above $40 \%$ of the total period of the specialty. At the same time, the college should actively create conditions and adopt various measures to enhance the utilization rate of the practice training laboratory and the base out of the college, actively organize teachers and experts to compile the practice teaching materials with strong actual efficiency and pertinence, and make students who participate in the actual training to have their own copies.

(2) The composing of the practical teaching. The practical parts to support the practice teaching include following aspects.

First, various courses should fully embody the application and practice of the courses. Teachers should strengthen the case teaching, establish the scene training, and emphasize to cultivate students' actual ability to utilize modern business knowledge and concepts to solve various problems and conflicts in the business practices.

Second, the college should develop a series of student practice activities with the color of specialty such as the contest of business plans, the contest of self-employment plans, the simulated business negotiation, the simulated business dissension intermediation and the judgment of business dissension cases.

Third, the main courses in the specialty should all require the teachers to organize students to simulate the business training in the specialty actual training laboratory, strengthen the instruction and management to cultivate students' competition consciousness and ability and improve students' understands to the enterprise operation and post responsibility.

Fourth, each graduate should complete his graduate design. The graduate design is based on the actual business management and application operation, and it can completely reflect graduates' cultivation targets and the achievement degree of the specification. Graduates must put in the post exercitation report and the practice project of above one business item.

Fifth, the college should actively organize students to participate in the training of the vocational qualification exam, and make above $95 \%$ students can acquire 1 2 vocational qualification certificates about the business.

Sixth, the social practice should be actively developed. The students should be organized to make market investigation and business affair disposal in the community and society in the holidays, periodically participate in actual training in the training base of the enterprise, and be familiar with relative business works of the enterprise, and instructed by the personnel of the enterprise.

By the exercitation and practical training, students' actual business ability can be integrated and enhanced, and they will more quickly be transformed from the dummy business personnel to the vocational business personnel.

\subsection{Constructing the vocational quality education system adapting professional cultivation targets}

Higher vocational graduates' vocational quality is composed by three parts including the vocational post ability, the vocational basic quality and the vocational emergency disposal ability, and it is comprehensive. The vocational post ability is the core, and it includes the theoretical knowledge, practical technology and special skills required by the vocational post, and the vocational basic quality includes the ideological quality, the humanistic social and science quality, the natural science quality and the physical psychological quality, and the vocational emergency disposal ability includes the self-learning ability, the innovation ability, the survival ability and the public relations ability.

First, the college should update the educational concept and comprehensively develop the vocational quality education. Various studies can be utilized to make teachers continually update their educational ideas and concepts, change the partial cognition which only emphasizes the specialty education or simply think the quality education means to develop some activities after school and cultural courses. The college should implement the thought of the vocational quality education into the whole talent cultivation plan to form the vocational quality education system.

Second, the college should strengthen the vocational moral education. In the practice of the teaching reform, the college should always persist in the "giving priority to moral education", emphasize the concept that "to do business should be 
a human first", strengthen the education of "being an upright person with honesty and doing business with honesty", improve the enhancement of the talent moral quality and the formation of the healthy civilization habit and the learning thinking habit, give prominence to the application and actual efficiency of the theoretical teaching and actual practice training, and bring up various business talents full of strong suits.

Third, the college should correctly deal with the relationships among interior factors in the vocational quality education, and set up relative courses according to the cultivation plan by two systems including the theoretical teaching and the practical teaching, actively develop the national vocational qualification exam and training, and try to reduce the application period after graduates enter into the posts of the enterprise.

Fourth, the college should organize abundant and color second classroom activities such as humanistic and science \& technology courses, professional skill contest, business plan contest, "challenge cup" invention contest, simulated court justice of economic court, and joint party of college and enterprise to offer stage for student to show themselves, cultivate their talents, edify their sentiments, enrich the school life and improve the good development of the schooling style and the teaching style.

Fifth, the college also can invite experts, scholars, schoolmates and enterprise leaders to make reports or perform symposia, set up many selectable courses such as literature, history, philosophy, arts and physics, encourage and organize students to participate in various social practices, which can open their eyes, develop their innovational potentials, improve their individuality development, promote and deepen their knowledge and cognitions about the vocational posts and the society.

\subsection{Reforming the teaching methods and measures, and the exam and evaluation system}

The college should persist in the concept that "the theory should take the sufficient use as the limit" to reform the teaching methods. And it should reform the teaching mode and method "based on work process and post demand", give prominence to students' main status, insist on multiple cultivation mode integrating mutual teaching interaction, school experiment and vocational training, scene simulation and post exercitation to train students' ability of self-learning and self-training.

\subsection{Reforming the exam and evaluation system, and strengthen the pertinence and actual efficiency of the exam}

According to the properties of the courses, many modes such as closed-book exam, open-book exam, discussion and discourse will be combined to test students' achievements in the theoretical courses. In the practice parts, the post actual operation, the project plan design, and the works design will be combines to organize the exams. And for part of courses, according to continually changing new knowledge and requirements, the comprehensive exam including multiple factors such as practice representation, practice evaluation and post exercitation performance will be adopted.

In the construction and practice of the talent cultivation mode of the business specialty, the conformation and implementation of many concrete implementation contents such as the organization institution, the teaching quality guarantee and control system, the relative matching policies, the teacher group construction, the experiment and actual training equipment construction, the charge investment and the talent cultivation plan are also necessary, which will be explained in other articles.

\section{References}

Chinese Ministry of Education. (2004). Advices to Deepen the Higher Vocational Education Reform Oriented by the Employment. No.1 Document of Higher Education.

Xiao Xiaokong. (2006). The Establishment of the Vocational Quality Education System Adapting Professional Cultivation Target. Journal of Teaching and Management. No.7. 